\title{
The relationship among job demand, job satisfaction, and job burnout of bank employees in Malang
}

\author{
E.Z. Firdaus, N. Noermijati \& K. Ratnawati \\ Management Department, Faculty of Economic and Business, Universitas Brawijaya, Indonesia
}

\begin{abstract}
The purpose of this study was to examine the direct effect of job demand and job burnout on job satisfaction and to see the mediating role of job burnout in the effect of job demand on job satisfaction of bank employees in Malang. The hypotheses were tested using the analysis tool partial least square (PLS) with the WarpPLS.7.0 program, based on data from 131 bank employees in Malang. As expected, the results of this study indicate that job demand has a significant negative direct effect on job satisfaction and significant positive direct effect on job burnout, but job burnout has no significant direct effect on job satisfaction. This research also shows that job burnout has no role in mediating the effect of job demand on job satisfaction.
\end{abstract}

\section{INTRODUCTION}

Technological developments require banks to continue to innovate by following the existing developments to continue to compete. One of the most important strategies is the digitization of human resource management. Employees are considered an important asset to the company. One of the most important things that employees should consider is the level of job satisfaction. Job satisfaction is considered hugely important within the field of human resources and organizational behavior. The level of job satisfaction is influenced by intrinsic and extrinsic motivational factors, the quality of supervision, social relationships with work groups, success rates, and individual failures in their work. (Armstroang, M. \& Taylor, S., 2014). Individual job failures can occur when employees are unable to meet the job demands and when they are experiencing burnout.

In the JDCS Model (Job demand/Control/Support Model), reduced job satisfaction is one of the negative contributions that result from high job demands, which then produce long-term psychological stimulation and discomfort, as well as long-term activation (Karasek, R., 1979; Karasek, R., 1998; Karasek, R. \& Theorell, T., 1990). Burned out employees are more likely to show greater absenteeism, higher turnover intention, as well as actual turnover, lower job satisfaction, and lower organizational commitment (Bakker et al., 2003; Maslach \& Leiter, 2008). The purpose of this study was to examine the direct effect of job demand and job burnout on job satisfaction and to see the mediating role of job burnout in the effect of job demand on job satisfaction of bank employees in Malang.

Job satisfaction is a feeling of pleasure or positive emotions that arise from assessing a job or experience at work (Luthans, F., (2011). In the JDCS Model, reduced job satisfaction is one of the negative contributions that result from high job demands, which then produce long-term psychological stimulation and discomfort, as well as long-term activation ((Karasek, R., 1979; Karasek, R., 1998; Karasek, R. \& Theorell, T., 1990). Supporting this opinion, the results of research by Lu, L. et al. (2015) and Hernandez, W. et al. (2018) show that job demand, as measured by the work constraints indicator, has a significant negative effect on job satisfaction. Based on the theoretical study and the results of the research, the following hypothesis can be formulated:

H1: Job demand has a significant negative effect on job satisfaction. 
The job demands-resources model extends the previous work-stress model to include demand and resources (Hakanen, J. et al., (2017). The integration between the job demand process and the job resource process (resources) can finally achieve a balance where an employee is challenged enough to stay involved in the workplace and is supported to avoid fatigue (Demerouti, E. \& Bakker, A., 2011). According to Hobfoll, S. E. and Freedy, J. (1993), job burnout develops from job demands and work environment. Several studies have shown that job demand has a significant positive effect on various job burnout indicators, as research results from the studies by Bakker, A. et al. (2004); Montgomery, A. et al. (2015); Alarcon, G. (2011); Hernandez, W. et al. (2018); Yener, M. and Coskun, O. (2013) indicate. Based on the theory and the research results, the following hypothesis can be formulated:

\section{H2: Job demand has a significant and positive direct effect on job burnout.}

Job burnout is a chronic, work-related affective state that develops gradually over time as a consequence of prolonged stress at work. (Sokka, L. et al., 2016). High job burnout was found to have a direct impact on employee job satisfaction levels. Supporting this opinion, the results of research by Chen, S. and Chen, C. (2018) and Muhammad, A. and Hamdy, H. (2005) show that job burnout has a significant negative direct effect on job satisfaction. In line with this, in the research by Kim, W. et al. (2017), the results of the direct effect analysis show that job burnout as measured by indicator exhaustion, cynicism, and professional inefficacy has a significant negative effect on job satisfaction. Based on the theoretical study and the results of the research, the following hypothesis can be formulated:

\section{H3: Job burnout has a significant negative effect on job satisfaction.}

The term job burnout was coined to describe a psychological syndrome characterized by negative emotional reactions to work as a result of prolonged exposure to a stressful work environment. (Maslach, C. et al., 2001). Hernandez, W. et al. (2018) found that job burnout has a significant direct effect on job demand and job satisfaction. The results of this study also indicate that job burnout moderates the effect of job demand on job satisfaction. Based on the theoretical study and the results of the research, the following hypothesis can be formulated:

H4: Burnout mediates the direct effect of job demand on job satisfaction.

\section{RESEARCH METHOD, DATA ANALYSIS, AND MEASUREMENT}

Quantitative research with survey methods was conducted in this study to obtain information from respondents. This research is a causal associative study aiming to explain the variables studied and the causal relationship between one variable and another. The study population was permanent employees with a minimum working period of 1 year. Questionnaires were distributed to 145 bank employees in Malang. The validity and reliability tests were conducted to measure questionnaire feasibility. Data analysis in this study was done using descriptive statistical analysis by analysis tool partial least square (PLS) with the WarpPLS.7.0 program. The mediation test was carried out using the Sobel test.

This study's job demand variables are measured by three indicators: qualitative demand, quantitative demand, and organizational demand. This study's indicators and job demand items refer to the questionnaire's measurement scale on the Experience and Evaluation of Work (QEEW) (Schaufeli, W., 2015; Schaufeli, W. 2017). This study's indicator for measuring job burnout variables refers to the Chinese version of the Maslach Burnout Inventory-General Survey (MBI-GS) (Hu \& Schaufeli, 2011; Schaufeli, W. et al., 1996), which consists of emotional exhaustion, depersonalization, and cynicism. Job satisfaction variables are measured in this study using overall job satisfaction indicators, including indicators of pride in work, loyalty to work, love of work, and satisfaction with work. Overall job satisfaction indicators in this study are taken from the works by Quarstein et al. (1992) and Crossman, A. and Abou-Zaki, B. (2003). 


\section{RESULT AND DISCUSSION}

\subsection{Research result}

Of the questionnaires that were distributed to bank employees in Malang, 131 were collected (88\%); $56.5 \%$ of them were female employees, with tenure levels in the range of $1-5(47.4 \%)$ years. Eighty-four employees were married (64.1\%), with ages ranging from 26 to $30(47.4 \%)$, and 112 employees had a bachelor's degree (85.5\%).

This hypothesis testing is done by looking at the results of the p-value. The criterion is significant if the p-value is less than 0.05 ; then $\mathrm{H} 0$ is accepted or significant. However, if the p-value is greater than 0.05 , then $\mathrm{H} 0$ is rejected or insignificant. The results of the analysis of hypothesis testing using the WarpPLS software application are as follows.

The $\mathrm{p}$-value for testing hypothesis 1 is 0.01 , and the path coefficient for direct influence is -0.39 . So hypothesis 1 is accepted, and it is concluded that job demand has a significant negative direct effect on job satisfaction. The p-value of the testing hypothesis 2 is 0.01 , and the path coefficient for direct influence is 0.44 . So hypothesis $\mathrm{H} 2$ is accepted, and it is concluded that job demand has a significant positive effect on job burnout. The coefficient value of the pathway for testing hypothesis 3 is -0.04 , and the p-value is 0.35 . So hypothesis 3 is rejected, and it can be concluded that job burnout has no significant direct effect on job satisfaction.

The fourth hypothesis in this study was conducted to examine the mediating role of job burnout. Testing the role of mediation is carried out using the Sobel test. The Sobel test results show that hypothesis 4 has a p-value of 0.309 and an estimated value of -0.497 . So hypothesis 4 is rejected, and it can be concluded that job burnout has no role in mediating the effect of job demand on job satisfaction.

\section{DISCUSSION}

Hypothesis 1 in this study is accepted, meaning that the job demand variable has a significant negative effect on the job satisfaction variable. Job demand negatively affects job satisfaction, meaning that the more job demands the employees must deal with, the less will be the level of job satisfaction felt by employees. These results support the results of previous research conducted by Karanika-Murray et al. (2017), who showed that job demands have a significant negative direct effect on job satisfaction. However, this study's results do not support any of the results of previous studies conducted by Nauman, S. et al. (2019), who showed that job demand does not have a significant direct effect on job satisfaction. On the other hand, in the research by Nauman, S. et al. (2019), it was also shown that emotional labor has a positive significant direct effect on job satisfaction. Many other factors can affect the level of employee job satisfaction. Armstrong, M. (2009) stated that the level of job satisfaction is influenced by intrinsic and extrinsic motivation factors, quality of supervision, social relations with workgroups and stages of success, and individual failure in their work.

Testing the direct effect of job demand on job burnout shows that there is sufficient evidence to accept hypothesis 2 , which states that job demand has a significant positive effect on job burnout. The positive path coefficient sign indicates a direct relationship between job demand and job burnout. These results suggest that the higher the job demands that the employees must fulfil, the higher the job burnout that employees will experience. The results of this study are similar to those of the research by Hakanen, J. et al. (2017); Montgomery, A. et al. (2015); and Hu, Q. et al. (2011). Schaufeli, W. et al. (2017) also showed that job demand has a significant positive effect on job burnout. The results of this study support the results of previous studies such as the research studies of Babakus, E. et al. (2009); Brauchli, R. et al. (2013); Chen, S. and Chen, C. (2018); Evers, A. et al. (2017); Wang, Y. et al. (2016); and Yener, M. and Coskun, O. (2013), which showed that job demand has no significant positive effect on job burnout. 
This study indicates that job burnout has no significant effect on job satisfaction, or in other words, hypothesis 3 is rejected. These results illustrate that job burnout does not have a significant direct effect on job satisfaction. These results do not support the results of previous studies conducted by Chen, S. and Chen, C. (2018); Kim, W. et al. (2017); and Muhammad, A. and Hamdy, H. (2005), which indicated that job burnout has a negative effect on job satisfaction. Many other factors can affect the level of job satisfaction of employees. Armstrong, M. (2009) stated that the level of job satisfaction is influenced by intrinsic and extrinsic motivational factors, the quality of supervision, social relationships with work groups, and levels of individuals' success and failure in their work.

The results of the Sobel test show that job burnout has no role in mediating the effect of job demand on job satisfaction. In other words, hypothesis 4 is rejected. The results of this study refute several previous studies that claim that high levels of burnout lead to lower job satisfaction, increased intentions for change and poor sleep quality, or even depression and suicide (Lu, A. \& Gursoy, D., 2016).

\section{CONCLUSIONS}

Research shows that job satisfaction is not directly influenced by job burnout; however, job satisfaction is directly influenced by job demand. Job demand also directly affects job burnout rates. Therefore, it is very important for companies, especially when considering the level of job demand that is given to employees. It is not easy to reduce the impact of job demand on employee burnout. Companies can try to change employee perceptions of job demands and, at the same time, make improvements in job resources. This action should significantly reduce work wear and tear and lead directly to higher performance.

\section{REFERENCES}

Alarcon, G. M. (2011). A meta-analysis of burnout with job demands, resources, and attitudes. Journal of Vocational Behavior, 79(2), 549-562. https://doi.org/10.1016/j.jvb.2011.03.007

Armstrong, M. (2009). Armstrong 'S Handbook Handbook of Human Resource Management Practice. 288. http://196.29.172.66:8080/jspui/bitstream/123456789/2178/1/152.pdf

Armstrong, M., \& Taylor, S. (2014). A Handbook of Human Resource Management Practice. Kogan Page Publishers. http://books.google.com/books?id=NVnd4s6JtioC\&pgis=1

Babakus, E., Yavas, U., \& Ashill, N. J. (2009). The Role of Customer Orientation as a Moderator of the Job Demand-Burnout-Performance Relationship: A Surface-Level Trait Perspective. Journal of Retailing, 85(4), 480-492. https://doi.org/10.1016/j.jretai.2009.07.001

Bakker, A. B., Demerouti, E., de Boer, E., \& Schaufeli, W. B. (2003). Job demand and job resources as predictors of absence duration and frequency. Journal of Vocational Behavior, 62(2), 341-356. https://doi.org/10.1016/S0001-8791(02)00030-1

Bakker, A. B., Demerouti, E., \& Verbeke, W. (2004). Using the job demands-resources model to predict burnout and performance. Human Resource Management, 43(1), 83-104. https://doi.org/10.1002/hrm.20004

Chen, S. C., \& Chen, C. F. (2018). Antecedents and consequences of nurses' burnout: Leadership effectiveness and emotional intelligence as moderators. Management Decision, 56(4), 777-792. https://doi. org/10.1108/MD-10-2016-0694

Crossman, A., \& Abou-Zaki, B. (2003). Job satisfaction and employee performance of Lebanese banking staff. Journal of Managerial Psychology, 18(4), 368-376. https://doi.org/10.1108/02683940310473118

Demerouti, E., \& Bakker, A. B. (2011). The Job Demands?Resources model: Challenges for future research. SA Journal of Industrial Psychology, 37(2), 1-9. https://doi.org/10.4102/sajip.v37i2.974

Evers, A. T., Yamkovenko, B., \& Van Amersfoort, D. (2017). How to keep teachers healthy and growing: the influence of job demands and resources. European Journal of Training and Development, 41(8), 670-686. https://doi.org/10.1108/EJTD-03-2017-0018

Hakanen, J. J., Seppälä, P., \& Peeters, M. C. W. (2017). High Job Demands, Still Engaged and Not Burned Out? The Role of Job Crafting. International Journal of Behavioral Medicine, 24(4), 619-627. https://doi.org/10.1007/s12529-017-9638-3 
Hernandez, W., Yanchus, N. J., \& Osatuke, K. (2018). Evolving the JD-R model: The moderating effects of job resources and burnout taxonomies. Organization Development Journal, 36(1), 31-53.

Hobfoll, S. E., \& Freedy, J. (1993). Conservation of resources: A general stress theory applied to burnout. In Professional burnout: Recent developments in theory and practice (pp. 115-133).

Hu, Q., Schaufeli, W. B., \& Taris, T. W. (2011). The Job Demands-Resources model: An analysis of additive and joint effects of demands and resources. Journal of Vocational Behavior, 79(1), 181-190. https://doi.org/10.1016/j.jvb.2010.12.009

Karanika-Murray, M., Michaelides, G., \& Wood, S. J. (2017). Job demands, job control, psychological climate, and job satisfaction: A cognitive dissonance perspective. Journal of Organizational Effectiveness, 4(3), 238-255. https://doi.org/10.1108/JOEPP-02-2017-0012

Karasek, R. (1998). Demand/Control model: a social, emotional, and physiological approach to stress risk and active behaviour development. In Encyclopaedia of Occupational Health and Safety, International Labour Office (4th ed, pp. 34.6-34.14). International Labour Office.

Karasek, R., \& Theorell, T. (1990). Healthy work: Stress, productivity and the reconstruction of working life. Basic Books, Inc.

Karasek Robert A., J. (1979). Job Demands, Job Decision Latitude, and Mental Strain: Implications for Job Redesign. Administrative Science Quarterly, 24(2), 285-308. http://www.jstor.org/stable/2392498

Kim, W. H., Ra, Y. A., Park, J. G., \& Kwon, B. (2017). Role of burnout on job level, job satisfaction, and task performance. Leadership and Organization Development Journal, 38(5), 630-645. https://doi. org/10.1108/LODJ-11-2015-0249

Lu, A. C. C., \& Gursoy, D. (2016). Impact of Job Burnout on Satisfaction and Turnover Intention: Do Generational Differences Matter? Journal of Hospitality and Tourism Research, 40(2), 210-235. https://doi.org/10.1177/1096348013495696

Lu, L., Lin, H. Y., Lu, C. Q., \& Siu, O. L. (2015). The moderating role of intrinsic work value orientation on the dual-process of job demands and resources among Chinese employees. International Journal of Workplace Health Management, 8(2), 78-91. https://doi.org/10.1108/IJWHM-11-2013-0045

Luthans, F. (2011). ORGANIZATIONAL BEHAVIOR: An Evidence-Based Approach (12th ed.). McGrawHill/Irwin.

Maslach, C., \& Leiter, M. P. (2008). Early Predictors of Job Burnout and Engagement. Journal of Applied Psychology, 93(3), 498-512. https://doi.org/10.1037/0021-9010.93.3.498

Maslach, C., Schaufeli, W. B., \& Leiter, M. P. (2001). Job Burnout. Encyclopedia of Mental Health: Second Edition, 52, 397-422. https://doi.org/10.1016/B978-0-12-397045-9.00149-X

Montgomery, A., Spânu, F., B?ban, A., \& Panagopoulou, E. (2015). Job demands, burnout, and engagement among nurses: A multi-level analysis of ORCAB data investigating the moderating effect of teamwork. Burnout Research, 2(2-3), 71-79. https://doi.org/10.1016/j.burn.2015.06.001

Muhammad, A. H., \& Hamdy, H. I. (2005). Burnout, supervisory support, and work outcomes: A study from an Arabic cultural perspective. International Journal of Commerce and Management, 15(3-4), 230-243. https://doi.org/10.1108/10569210580000199

Nauman, S., Raja, U., Haq, I. U., \& Bilal, W. (2019). Job demand and employee well-being: A moderated mediation model of emotional intelligence and surface acting. Personnel Review, 48(5), 1150-1168. https://doi.org/10.1108/PR-04-2018-0127

Quarstein, V.A., McAfee, R. B., \& Glassman, M. (1992). The situational occurrences theory of job satisfaction. Human Relations, 45(8), 859-873. https://doi.org/10.1177/07399863870092005

Schaufeli, W. B. (2015). Engaging leadership in the job demands-resources model. Career Development International, 20(5), 446-463. https://doi.org/10.1108/CDI-02-2015-0025

Schaufeli, W. B. (2017). Applying the Job Demands-Resources model: A 'how to' guide to measuring and tackling work engagement and burnout. Organizational Dynamics, 46(2), 120-132. https://doi.org/10.1016/j.orgdyn.2017.04.008

Sokka, L., Leinikka, M., Korpela, J., Henelius, A., Ahonen, L., Alain, C., Alho, K., \& Huotilainen, M. (2016). Job burnout is associated with dysfunctions in brain mechanisms of voluntary and involuntary attention. Biological Psychology, 117, 56-66. https://doi.org/10.1016/j.biopsycho.2016.02.010

Wang, Y., Huang, J., \& You, X. (2016). Personal resources influence job demands, resources, and burnout: A one-year, three-wave longitudinal study. Social Behavior and Personality, 44(2), 247-258. https://doi. org/10.2224/sbp.2016.44.2.247

Yener, M., \& Coskun, Ö. (2013). Using Job Resources and Job Demands in Predicting Burnout. ProcediaSocial and Behavioral Sciences, 99, 869-876. https://doi.org/10.1016/j.sbspro.2013.10.559 